\title{
Microbial Quality of Frozen Chicken Parts from three Import Countries into the Kumasi Metropolis of Ghana
}

${ }^{1}$ Denis Dekugmen Yar ${ }^{*}{ }^{2}$ William K. J. Kwenin, ${ }^{1}$ Winfred Kwame Zanu, ${ }^{1,3}$ Gadafi Iddrisu Balali, ${ }^{1}$ Enos Kwame Adepa, ${ }^{1}$ Gyapong Francis

${ }^{1}$ Department of Science Education, University of Education, Winneba (Mampong Campus)

${ }^{2}$ Department of Animal Science Education, University of Education, Winneba (Mampong Campus)

${ }^{3}$ Department of Theoretical and Applied Biology, Kwame Nkrumah University of Science and Technology, Kumasi, Ghana.

\author{
The Corresponding author* \\ ${ }^{1}$ Department of Science Education, University of Education, Winneba - Mampong Campus. \\ Email: ddyar@uew.edu.gh MOB +233243236810
}

\begin{abstract}
Background: There is an upsurge in the consumption of chicken meat leading to a high influx of imported frozen chicken parts into the Ghanaian markets with little information on their microbial qualities. This study examined the microbial quality of imported frozen chicken parts from three major import countries (USA, the Netherlands and Brazil) into the Kumasi Metropolis.

Methods: A total of 45 chicken meat parts of 15 thighs, wings and backs from wholesale cold stores market in the Kumasi Metropolis were randomly sampled for laboratory examinations. A ten-fold serial dilution was performed on each homogenized chicken parts to determine microbiological quality using Plate Count Agar [1], MacConkey Agar (MCA), Mannitol Salt Agar (MSA) and Desoxycholate Citrate Agar (DCA) for the total viable count (TVC), total coliform count (TCC), Staphylococcus and Salmonella spp counts respectively incubated at $37^{\circ} \mathrm{C}$ for 48 hours. Sabouraud Dextrose Agar (SDA) was used for fungal counts. We identified bacterial and fungal isolates using appropriate laboratory and biochemical tests. Descriptive data analysis was carried using SPSS-IBM version 16.
\end{abstract}

Results: Mean TVCs of 5.93, 5.98 and $6.14 \log _{10} \mathrm{cfu} / \mathrm{g}$ were recorded for frozen chicken meats from the USA, the Netherlands and Brazil respectively. Means TCCs of 6.14, 5.93 and 5.98 $\log _{10} \mathrm{cfu} / \mathrm{g}$ were obtained for chicken meats from Brazil, USA and the Netherlands respectively. Staphylococcus spp. (35.4\%), E. coli (26.2\%), Salmonella spp. (24.6\%), and Klebsiella spp. (13.8\%) were isolated with Aspergillus spp (33.3\%), Rhizopus spp (27.3\%), Penicillin spp (24.2\%), and Cladosporium spp (15.2\%). Chicken thighs, backs and wings recorded 46.2\%, 29.2\% and $24.6 \%$ bacterial contaminants in this order. Bacterial isolates of $49.2 \%, 28.8 \%$ and $22.0 \%$ were recorded in frozen chicken meat products from Brazil, the Netherlands USA respectively.

Conclusion: The results suggest that imported frozen chicken meats into the Ghanaian market have moderate quality with potential pathogens such as E. coli and Salmonella spp.

Keywords: Microbial quality, frozen chicken meat. 


\subsection{Introduction}

Poultry production is dominated by chicken in many parts of the world due to the relative ease of its production [2] and serve as a major source of animal protein [3]. Meanwhile, chicken meat is known to cause many zoonotic foodborne infections in the world [4]. Global food production and consumption systems, therefore, required that food quality and safety be scrutinized and examined for public health safety $[5,6]$. Poultry and poultry meat are however prone to contaminations with potentially pathogenic microorganisms such as Salmonella, Campylobacter, S. aureus, E. coli and Listeria [7].

In Ghana, local broiler meat production is estimated at 35,000 tons, less than $25 \%$ of local demand [8]. Meanwhile, there is an upsurge in chicken meat consumption with a corresponding increase in demand for frozen chicken products $[9,10]$. An expected 14,000 to 158,000 tons is therefore required local demand [8] and this led to an influx of imported frozen chicken parts. Moreover, market prices of local broiler meat are 30-40\% margin higher than imported frozen chicken meat making local poultry production uncompetitive $[8,11,12]$. Furthermore, consumers prefer imported frozen chicken products because these come pre-cut parts of legs-quarters, thighs, breasts and wings and are affordable [13, 14].

Due to International Trade Liberation, the Ghanaian markets are inundated with frozen chicken products from major import nations such as the United States of America (USA), the Netherlands and Brazil whose microbial qualities cannot be guaranteed [15]. The Kumasi Metropolitan Assembly and the Food and Drugs Authority of Ghana frequently ceased expired frozen chicken during routine surveillance at the Asafo market. However, there is a paucity of data on the microbial quality of pre-cut and packaged imported chicken meat products in the Kumasi Metropolis of Ghana [16].

This study, therefore, assessed and compared the microbial quality of imported frozen chicken parts from three major import countries (United States of America, the Netherlands and Brazil) into the Kumasi Metropolis of Ghana. 


\subsection{Conceptual Framework}

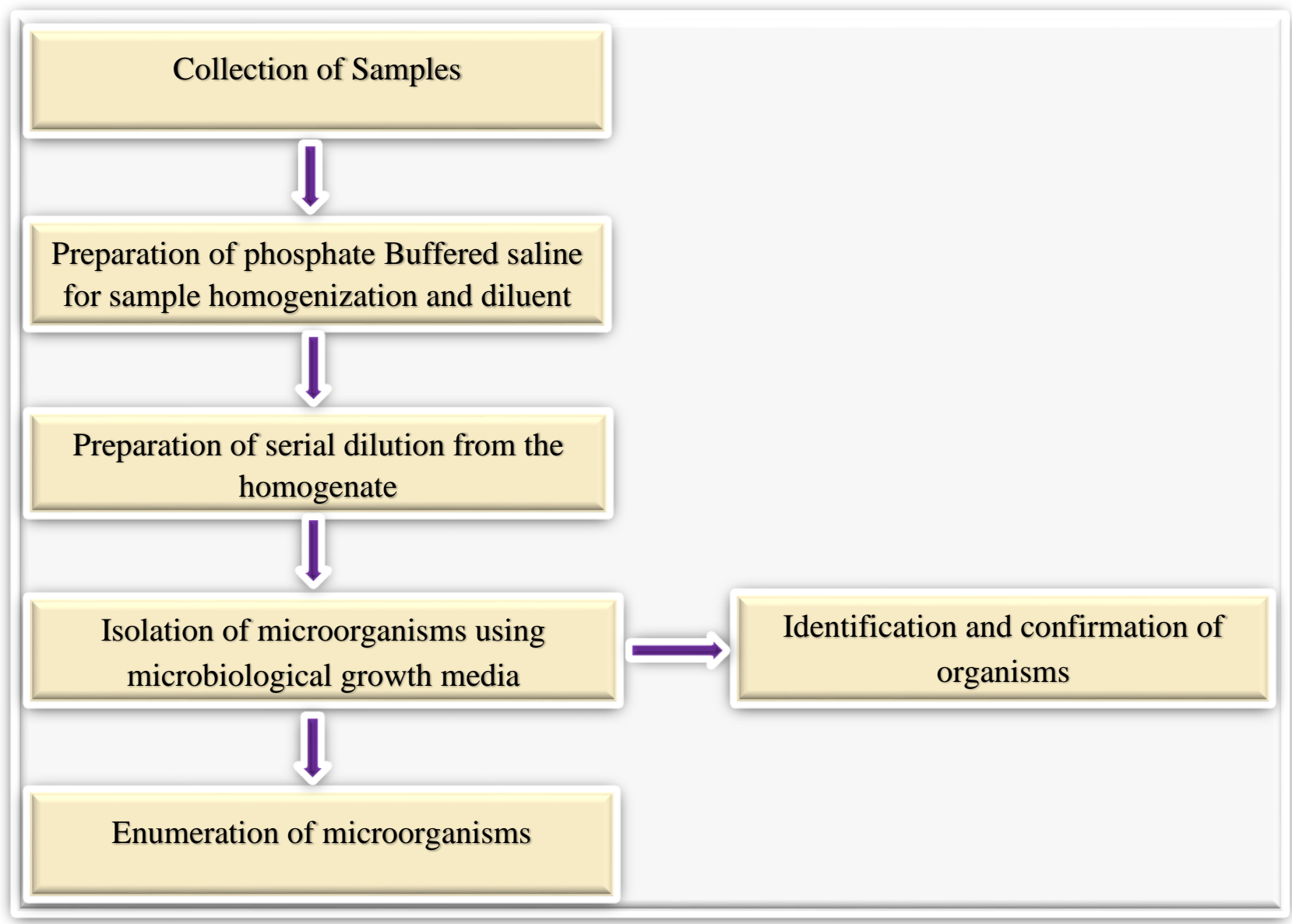

Figure 1: Schematic flow chart of the research design used in this study

\section{Methodology}

\subsection{Study Area}

The study site was the Asafo Market in the Kumasi Metropolis (Figure 2). The market is a major hub for wholesale cold stores and is a repertoire for about $95 \%$ of all imported frozen meats and fishes from the Tema harbour of Ghana. Poultry production in the metropolis accounted for $28.07 \%$ of the total poultry production in Ghana [17]. Ashanti Region is located in the middle belt and the third largest of the 16 administrative regions in Ghana. Kumasi Metropolis has an estimated population of $1,730,249 ; 36.2 \%$ of the regional population [17]. The region has $10.2 \%$ of the total land area of Ghana with a population of 4,780,380. The region lies between longitudes $0.15 \mathrm{~W}$ and $2.25 \mathrm{~W}$, and latitudes $5.50 \mathrm{~N}$ and $7.46 \mathrm{~N}$ and has 27 districts with Kumasi the regional capital. 


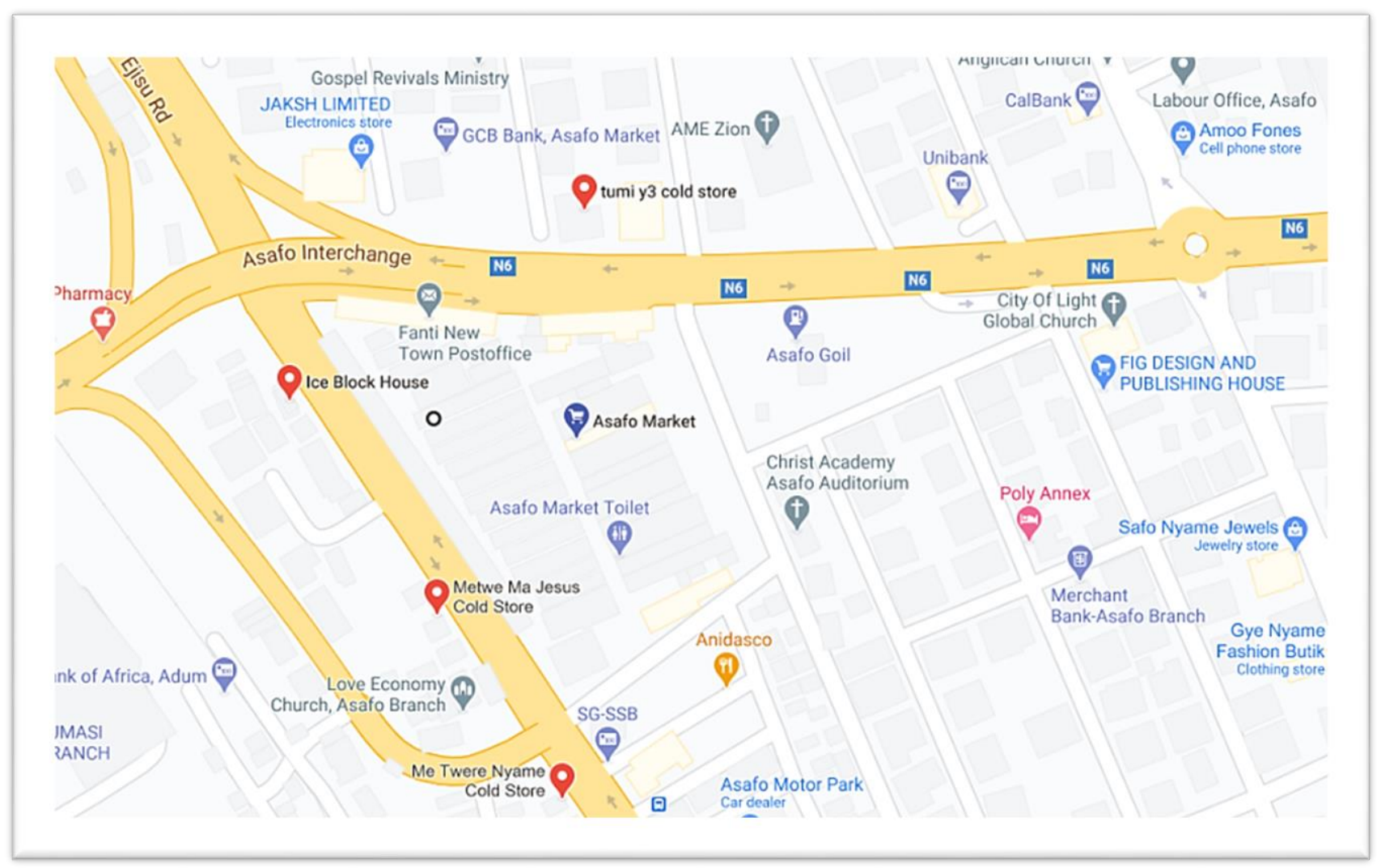

Figure 2: Map showing some major cold stores at Asafo Meat Hub (Source: Google map)

\subsection{Study Design}

This was a descriptive cross-sectional study designed to assess the microbiological quality of imported chicken parts sold in wholesale cold stores at the Asafo Market in the Kumasi Metropolis of Ashanti Region, Ghana.

\subsection{Study Population and Size}

A total of 30 licensed importers with large wholesale cold stores for frozen chicken at the Asafo market were involved. Three chicken parts (thighs, wings, and backs) were each collected from the three import countries (United State of America, Brazil and the Netherlands). A sample size of 45 comprising of 5 each of pre-cuts chicken thighs, wings, and backs from each import country was collected. 


\subsection{Sampling Technique}

Multistage sampling; purposive, stratified and simple random techniques were employed. Firstly, wholesale import cold stores with frozen chicken meats from the three import countries (USA, Brazil and the Netherland) were purposively selected. Stores were further stratified into three import countries from which at least four cold stores were randomly sampled from each group. Five newly arrived cartons of frozen chicken parts (chicken thighs, wings, backs) were then purchased from each import country for the study (table 1). These were transported under the ice to the laboratory for analysis.

Table 1: Sample size from major cold stores

\begin{tabular}{ccccc}
\hline $\begin{array}{c}\text { Country Of } \\
\text { Import }\end{array}$ & Wings & \multicolumn{2}{c}{ Chicken Parts } & \\
Backs & 5 & Thighs & Total \\
\hline USA & 5 & 5 & 5 & 15 \\
Brazil & 5 & 5 & 5 & 15 \\
the Netherlands & 5 & $\mathbf{1 5}$ & 5 & 15 \\
Total & $\mathbf{1 5}$ & $\mathbf{1 5}$ & $\mathbf{4 5}$ \\
\hline
\end{tabular}

\subsection{Sampling Procedures}

Aseptic sampling techniques were used to sample one kilogram of frozen chicken parts (thighs, wings and back) from each carton into sterile plastic envelope bags, sealed, and stored under the ice for the microbiological analysis.

\subsection{Laboratory Methods and Analysis}

\subsubsection{Media and Reagent for Bacteriological Study}

Media used for microbial analysis were Plate Count Agar [1], MacConkey Agar (MCA), Mannitol Salt Agar (MSA), Desoxycholate Citrate Agar (DCA) and Sabouraud Dextrose Agar (SDA). All commercial media were prepared as previously described $[18,19]$.

\subsubsection{Sample Preparation}

A $25 \mathrm{~g}$ portion of each chicken parts were excised aseptically into a sterile stomacher bag containing $225 \mathrm{ml}$ of sterile buffered peptone water and homogenized. Each homogenate was then used for serial dilution.

\subsubsection{Serial Dilution and Culturing}

A ten-fold serial dilution was performed on each homogenate for cultivation and identification of microbial contaminants as previously described [18, 19]. Meanwhile, fungal isolates were 
enumerated and identified by morphological characteristics on Sabouraud Dextrose Agar (SDA) incubated at room temperature [20].

\subsection{Microbial Analysis}

Total Viable Counts (TVC), Total Coliform Counts (TCC), Salmonella species counts, Staphylococcus species counts were determined using $1 \mathrm{ml}$ dilution of each sample on suitable media and incubated at $37^{\circ} \mathrm{C}$ for 24 hours as previously described [18, 19]. Bacterial isolates on the different media were identified using standard microbiological methods [21]. Using representative colonies, isolates were sub-cultured and identified using morphological characteristics and standard biochemical tests previously described [18, 19].

\subsection{Identification of Fungi}

The fungal isolates were identified by their morphological characteristics on Sabouraud Dextrose Agar (SDA) and microscopic examination using lactophenol cotton blue staining technique as previously described $[20,22]$.

\section{9 Statistical Analysis}

Data obtained from the microbial analysis were entered into Microsoft excel 2007 spreadsheet. The means microbial counts were computed (cfu/g) and transformed into $\log _{10} \mathrm{cfu} / \mathrm{g}$. The data was subsequently imported into IBM-SPSS software version 16.0 and analyzed. Descriptive statistics were used to summarize the distribution of various variables into tables and figures. The mean counts of the three chicken parts and the country of import were compared using one-way analysis of variance (ANOVA) at a $95 \%$ confidence interval $(\mathrm{P}<0.05)$.

\section{Results}

\subsection{Mean Bacterial Counts of frozen Chicken parts per import country}

Table 2 shows the mean $\log$ cfu/g counts of TCC, TVC, and Salmonella and Staphylococcus aureus for chicken meats from the three import nations. Chicken meat parts from Brazil had means TCC of 6.14 mean $\log _{10} \mathrm{cfu} / \mathrm{g}$ whereas the Netherlands was 5.98 mean $\log _{10} \mathrm{cfu} / \mathrm{g}$. Chicken meats from Brazil recorded TVC of 6.14 mean $\log _{10} \mathrm{cfu} / \mathrm{g}$ whereas the least was from the USA. The highest counts for Salmonella species and Staphylococcus aureus were from the USA. There were 
no significant differences $(\mathrm{P}>0.05)$ in mean counts for chicken parts in the USA, the Netherlands and Brazil.

Table 2: Mean bacterial load log count of chicken meat per import country

\begin{tabular}{lcccccccc}
\hline \multicolumn{1}{c}{ Import } & \multicolumn{2}{c}{ TVC (cfu/g) } & \multicolumn{2}{c}{ TCC(cfu/g) } & \multicolumn{2}{c}{ Salmonella(cfu/g) } & \multicolumn{2}{c}{ S. aureus(cfu/g) } \\
\hline \multicolumn{1}{c}{ nation } & Mean & Log & Mean & Log & Mean & Log & Mean & Log \\
\hline USA & $8.5 \times 10^{5}$ & $5.93( \pm 0.32)$ & $4.0 \times 10^{4}$ & $4.6( \pm 0.26)$ & $5.1 \times 10^{4}$ & $4.71( \pm 0.13)$ & $4.4 \times 10^{4}$ & $4.64( \pm 0.18)$ \\
The Netherlands & $9.5 \times 10^{5}$ & $5.98( \pm 0.39)$ & $6.5 \times 10^{4}$ & $4.81( \pm 0.28)$ & $1.7 \times 10^{4}$ & $4.22( \pm 0.54)$ & $3.2 \times 10^{4}$ & $4.51( \pm 0.18)$ \\
Brazil & $1.4 \times 10^{6}$ & $6.14( \pm 0.08)$ & $7.6 \times 10^{4}$ & $4.88( \pm 0.17)$ & $4.7 \times 10^{4}$ & $4.67( \pm 0.26)$ & $4.0 \times 10^{4}$ & $4.59( \pm 0.36)$ \\
\hline
\end{tabular}

TVC: Total Viable Count, TCC: Total Coliform Count. Permissible levels of bacterial load log counts (TVC: $\leq 6.48$, TCC: $\leq 4.0$, SC: absence per gram, STC: $\leq 4.0$, YMC: $\leq 5.3$ ) [23-25].

Table 3 shows the mean TVC, TCC, Salmonella spp. and Staphylococcus aureus counts for chicken thighs, backs, and wings showing no significant differences $(\mathrm{P}>0.05)$.

Table 3: Mean bacterial load counts of chicken parts

\begin{tabular}{lllllllll}
\hline Chicken & \multicolumn{2}{c}{ TVC $(\mathrm{cfu} / \mathrm{g})$} & \multicolumn{2}{c}{ TCC(cfu/g) } & \multicolumn{2}{c}{ Salmonella $(\mathrm{cfu} / \mathrm{g})$} & \multicolumn{2}{c}{ S. aureus $(\mathrm{cfu} / \mathrm{g})$} \\
Parts & Mean & Log & Mean & Log & Mean & Log & Mean & Log \\
\hline Thighs & $1.8 \times 10^{6}$ & 6.25 & $3.5 \times 10^{4}$ & 4.55 & $5.4 \times 10^{4}$ & 4.73 & $3.5 \times 10^{4}$ & 4.54 \\
Backs & $6.2 \times 10^{5}$ & 5.79 & $6.3 \times 10^{4}$ & 4.80 & $4.7 \times 10^{4}$ & 4.67 & $2.9 \times 10^{4}$ & 4.46 \\
Wings & $1.0 \times 10^{6}$ & 6.01 & $8.5 \times 10^{4}$ & 4.93 & $1.6 \times 10^{4}$ & 4.21 & $5.5 \times 10^{4}$ & 4.74 \\
\hline
\end{tabular}

TVC: Total Viable Count, TCC: Total Coliform Count. Permissible levels of bacterial load log counts (TVC: $\leq 6.48$, TCC: $\leq 4.0$, SC: absence per gram, STC: $\leq 4.0$, YMC: $\leq 5.3)[23-25]$.

\subsection{Bacteria isolates}

Table 4 shows the number of bacteria isolated from chicken meat products from the three import countries. Out of 45 chicken parts sampled, Brazil recorded 29 (49.2\%) isolates whereas the USA recorded 13 (22.0\%). Staphylococcus aureus was the highest (35.4\%) isolate followed by E. coli (26.2\%) and Salmonella spp. (24.6\%).

Table 4: Prevalence of Bacteria Isolates per Import country

\begin{tabular}{lllll}
\hline Import Nations & USA $(* \mathrm{n} / \%)$ & $\begin{array}{l}\text { The Netherlands } \\
(* \mathrm{n} / \%)\end{array}$ & Brazil $(* \mathrm{n} / \%)$ & Total $(\mathrm{N} / \%)$ \\
\hline Bacterial Isolates & & & & \\
Escherichia coli & $3(20.0)$ & $6(40.0)$ & $8(53.3)$ & $17(26.2)$ \\
Salmonella species & $2(13.3)$ & $5(33.3)$ & $9(60)$ & $16(24.6)$ \\
Klebsiella species & $2(13.3)$ & $4(26.7)$ & $3(20.0)$ & $9(13.8)$ \\
Staphylococcus aureus & $6(40.0)$ & $8(53.3)$ & $9(60 \%)$ & $23(35.4)$
\end{tabular}


Total (\%) $13(22.0)$ 23(28.8) 29(49.2) $65(100)$

$* n=15 ; * N=65 ;$ Not significantly different $(P>0.05)$

Table 5 shows the number of bacteria isolated on chicken parts from the three countries of import. Chicken thighs had the highest numbers of isolates $(46.2 \%)$, followed by backs $(29.2 \%)$ and wings $(24.6 \%)$.

Table 5: Frozen Chicken Parts per Bacteria Isolates

\begin{tabular}{lcccc}
\hline Frozen chicken parts & Thighs $\left(*_{\mathrm{n}} / \%\right)$ & Wings $\left(*^{*} \mathrm{n} / \%\right)$ & Back $\left(*^{*} \mathrm{n} / \%\right)$ & Total (N/\%) \\
\hline Bacterial Isolates & & & & \\
Escherichia coli & $7(46.7)$ & $4(26.7)$ & $6(40.0)$ & $17(26.2)$ \\
Salmonella species & $6(40.0)$ & $6(40.0)$ & $4(26.7)$ & $16(24.6)$ \\
Klebsiella species & $4(26.7)$ & $2(13.3)$ & $3(20.0)$ & $9(13.8)$ \\
Staphylococcus aureus & $13(86.7)$ & $4(26.7)$ & $6(40.0)$ & $23(35.4)$ \\
Total $(\%)$ & $30(46.2)$ & $16(24.6)$ & $19(29.2)$ & $65(100)$ \\
\hline
\end{tabular}

$*_{n}=15 ; * N=65 ;$ No significantly different $(P>0.05)$

\subsection{Fungi Isolates}

In Table 6, mean $\log \mathrm{cfu} / \mathrm{g}$ for fungal counts for chicken products were 2.03, 2.06 and 1.97 for the USA, the Netherlands and Brazil respectively.

Table 6: Plate Count for Fungi

\begin{tabular}{lccccc}
\hline Countries of import & Thighs & Wings & Back & Total & $\begin{array}{c}\text { Mean Log } \text { Log }_{10} \\
\text { CFU/g }\end{array}$ \\
\hline USA & 2.04 & 2.01 & 2.04 & 6.09 & 2.03 \\
The Netherlands & 2.03 & 2.08 & 2.06 & 6.17 & 2.06 \\
Brazil & 1.98 & 1.92 & 2.02 & 5.92 & 1.97 \\
\hline
\end{tabular}

Permissible levels of bacterial load log counts (TVC: $\leq 6.48$, TCC: $\leq 4.0$, SC: absence per gram, STC: $\leq$ 4.0, YMC: $\leq 5.3)[23-25]$.

Table 7: Fungal genera Identified per import country

\begin{tabular}{lccccc}
\hline Import Nation & Cladosporium & Aspergillus & Penicillin & Rhizopus & Total (\%) \\
\hline USA & $2^{*}$ & $3^{*}$ & $2^{*}$ & $3^{*}$ & 30.3 \\
The Netherlands & $1^{*}$ & $5^{*}$ & $3^{*}$ & $3^{*}$ & 36.4 \\
Brazil & $2^{*}$ & $3^{*}$ & $3^{*}$ & $3^{*}$ & 33.3 \\
Total (\%) & 15.2 & 33.3 & 24.2 & 27.3 & 100 \\
\hline
\end{tabular}

Permissible levels of bacterial load log counts (TVC: $\leq 6.48$, TCC: $\leq 4.0$, SC: absence per gram, STC: $\leq$ 4.0, YMC: $\leq 5.3)[23-25]$.

In Table 7, of twenty-five (25) fungal growths, four fungi genera were identified including 33.3\% (11) Aspergillus spp, 15.2\% [26] Cladosporium spp, $24.2 \%$ (8) Penicillin spp and Rhizopus spp 
$27.3 \%$ (9). Out of the 45 chicken sampled, a total of $25(55.56 \%)$ had fungal growth of which $28 \%$, $32 \%$ and $44 \%$ were isolated from the USA, the Netherlands and Brazil respectively

\subsection{Discussion}

\subsection{Microbiological Quality}

In this study, means total aerobic plate count of $>5 \log _{10} \mathrm{cfu} / \mathrm{g}$ were reported for imported frozen chicken parts from the USA, the Netherlands and Brazil consistent with previous studies in Ghana and the Czech Republic [27, 28]. Meanwhile, Kunadu et al. (2020) and Pesewu et al., (2018) reported higher bacteria counts for chicken meats at informal live bird markets and supermarkets in Ghana $[15,29]$. On the other hand, higher counts of $8.44 \log _{10} \mathrm{cfu} / \mathrm{g}$ and $10.17 \log _{10} \mathrm{cfu} / \mathrm{g}$ were reported for market chicken meats in Ouagadougou, Burkina Faso [30] and Nepal [31] respectively.

Mean total coliform counts and Salmonella counts of $>4 \log _{10} \mathrm{cfu} / \mathrm{g}$ were reported in this study consistent with $4.97 \log _{10} \mathrm{cfu} / \mathrm{g}$ and $6.5 \log _{10} \mathrm{cfu} / \mathrm{g}$ reported in previous studies $[32,33]$. The means counts in our study were higher than 3.14 to $3.80 \log _{10} \mathrm{cfu} / \mathrm{g}$ reported for chicken meat products from supermarkets in Ghana [28]. Higher coliform counts of $7.0 \log _{10} \mathrm{cfu} / \mathrm{g}$ and $32.2 \log _{10} \mathrm{cfu} / \mathrm{g}$ were also reported in previous studies contrary to this study $[34,35]$. In this study, total Staphylococci spp. of $>4 \log _{10} \mathrm{cfu} / \mathrm{g}$ were reported in agreement with previous studies $[35,36]$ but higher than $1.99 \log _{10} \mathrm{cfu} / \mathrm{g}$ reported in market meat elsewhere [37].

We suspect that the differences in bacteria counts for chicken meats in this study and previous studies might be linked to technologies used, hygienic conditions during slaughtering, processing, packaging, storage and distribution [37-40]. A study using ISO 22000:2005 certified poultry processing plant reported remarkable reductions in bacteria counts in the four sequential processing steps $[37,39]$. The final washing, freezing and packaging are the critical control point identified to control microbial contaminations [37, 39]. These processes might differ for poultry processing plants for each import country and hence the differences.

\subsection{Bacteria isolates}

Klebsiella spp., Salmonella spp., Staphylococcus aureus, and Escherichia coli were microbial contaminants isolated in this study. These bacteria are common contaminants of poultry meats [37]. Microbial contaminations occurred largely at evisceration due to faecal material from the 
cloaca of chicken carcasses [41]. Moreover, frozen chicken meat products imported into Ghana are subjected to several freeze-thaw cycles during transportation over long distances, through transit from ports to cold storage facilities providing favourable conditions for microbial proliferation. The presence of these bacteria is an index of the hygiene quality of the chicken meat. Several studies also reported similar microbial contaminants consistent with this study [42, 43].

Chicken products from Brazil recorded the highest bacterial isolates relative to the Netherlands and USA. We suspect the differences could result from differences in technologies employed in poultry husbandry and processing of the meats [40]. Also, the animal health, rearing conditions, quality of slaughtering, processing, packaging and storage conditions [44, 45]. Although largescale slaughterhouses is a rapid and highly automated process, notwithstanding, considerable opportunities exist for contamination [46, 47]. Hence, the performance of the slaughter process is very critical and has a direct consequence on the microbial quality of the chicken meat products [48]. This could have accounted for the observed differences in numbers of the bacteria isolates.

We obtained $26.2 \%$ and $24.6 \%$ prevalence for E. coli and Salmonella of which more than $50 \%$ were recorded for frozen chicken meat products from Brazil. These values are much lower than $66.7 \%$ and $91.7 \%$ reported for frozen chicken meat at retail outlets in Ghana [16]. These values in our study were fairly consistent with $27.82 \%$ and $13.64 \%$ obtained for Escherichia coli and Salmonella spp. but inconsistent with $18.52 \%$ and $1.84 \%$ for Staphylococcus aureus and Klebsiella spp. reported in Nigeria [43]. The presence of 35.4\% S. aureus in chicken meat products of this study is inconsistent with $17.9 \%$ obtained by Kozačinski and colleagues in Croatia [32]. The presence of $24.6 \%$ Salmonella of this study is fairly similar to $20 \%$ reported in broiler chicken [49] but much lower than $91.7 \%$ in chicken drumstick [16].

The presence of S. aureus, E. coli and Salmonella points to possible contamination at the plants coupled with transportation and storage challenges [50] and raises microbial safety standard credibility. The mere presence of these bacteria in raw meat may not necessarily pose a health threat to consumers since the meats would be subjected to cooking. Compared with the permissible limits stipulated by [23-25] for coliforms counts, S. aureus, E. coli and Salmonella spp. counts for chicken breast, backs and thigh samples examined were slightly higher and unacceptable. 


\subsection{Fungal Isolates}

Fungal contaminants, Aspergillus, Penicillium, Cladosporium and Rhizopus were isolated, consistent with previous studies [50]. Aspergillus and Rhizopus species were reported in chicken meat retailed in Lahore City, Pakistan [51] in agreement with this study. Candida and Cryptococcus spp. reported in poultry meat (drumstick and breast) retailed in Local Iraqi Markets [52] were not reported in our study. The presence of $33.3 \%$ Aspergillus spp. and $24.2 \%$ of Penicillin spp. in our study are in agreement with $35.7 \%$ and $21.4 \%$ reported for Aspergillus spp. and Penicillin spp. for processed chicken meat retailed in Abakaliki, Ebonyi State, Nigeria [53]. However, Neocosmospora spp. and Mucor spp. reported by [53] were not found in this study.

Fungal contaminations in chicken meat products may occur due to improper processing and temperature fluctuation during storage and transportation [22, 50]. The presence of fungal contaminants in chicken meat products poses a health threat to consumers. Some fungi under certain environmental conditions release secondary metabolites such as mycotoxins which could cause serious disorders in humans and animals [54]. Mycotoxins such as aflatoxins, ochratoxins, etc. produced by fungi like Aspergillus, Fusarium and Penicillium [55, 56] in food could cause severe health problems such as allergic reactions, cancer, and organ damage [57]. Although, there is a paucity of information on the acceptable limits for fungal contaminants in water and food, the presence of mycotoxigenic fungi pose public health concerns.

\subsection{Conclusion}

The results of this study highlighted the microbial quality of pre-cut imported frozen chicken meats into the country stored in major cold stores in the Kumasi metropolis. The presence of potential foodborne pathogens is linked to possible contaminations at slaughterhouses and transportation from ports to cold storage facilities over long distances with several freeze-thaw cycles. Therefore regular monitory by regulatory authorities together with stakeholders is critical to ensure frozen chicken imported into the country are safe for public health good.

\section{Acknowledgements}

We wish to acknowledge the efforts of Madam Gloria Pokua, Mr. Anthony Afrane, Mr. Samuel Frimpong Tenkorang and Madam Ajara Kwao Zakaria all in the Department of Science Education, University of Education, Winneba Mampong Campus, who participated in some data collection and some laboratory analysis. 


\section{Funding}

This was funded by the authors.

\section{Availability of supporting data}

All data used for this manuscript are available upon a reasonable request.

\section{Author(s) information}

Affiliations

${ }^{1}$ Denis Dekugmen Yar, ${ }^{1}$ Winfred Kwame Zanu, ${ }^{2}$ William K. J. Kwenin, ${ }^{1,3}$ Gadafi Iddrisu Balali,

${ }^{1}$ Enock Kwame Adepa, ${ }^{1}$ Gyapong Francis

${ }^{1}$ Department of Science Education, University of Education, Winneba - Mampong Campus

${ }^{2}$ Department of Animal Science Education, University of Education, Winneba - Mampong Campus

${ }^{3}$ Department of Theoretical and Applied Biology, Kwame Nkrumah University of Science and Technology, Kumasi, Ghana.

\section{The Corresponding author*}

${ }^{1}$ Department of Science Education, University of Education, Winneba - Mampong Campus.

Email: ddyar@uew.edu.gh MOB +233243236810

\section{Contributions}

DDY conceptualized and drafted the manuscript, WKZ collected the data and conducted the laboratory analyses, WKJK (Meat Scientist) critically edited the manuscript, and GIB reviewed and structured manuscript for publication, EKA (Laboratory Technician) supervised the laboratory analysis, GF reviewed the manuscript and accepted it for publication. All authors finally read and approved the manuscript for publication.

\section{Ethics declarations}

N/A

\section{Ethics approval and consent to participate}

N/A

\section{Consent for publication}

We have all read the final manuscript and consented it for publication.

\section{Competing interests}

We (authors) declare that there is no any competing interest.

\section{REFERENCES}

1. Dowson, A., et al., New guidelines for the management of migraine in primary care. Current medical research and opinion, 2002. 18(7): p. 414-439. 
2. Mottet, A. and G. Tempio, Global poultry production: current state and future outlook and challenges. World's Poultry Science Journal, 2017. 73(2): p. 245-256.

3. Cadudal, F., Global poultry meat market: retrospective analysis \& recent dynamics. $12 \mathrm{e}$ Journées de la Recherche Avicole et Palmipèdes à Foie Gras (JRA-JRPFG 2017), 5 \& 6 avril 2017, Tours, France, 2017: p. 1-10.

4. Rouger, A., O. Tresse, and M. Zagorec, Bacterial contaminants of poultry meat: sources, species, and dynamics. Microorganisms, 2017. 5(3): p. 50.

5. Wahyono, N. and M. Utami. A review of the poultry meat production industry for food safety in Indonesia. in J Phys Conf Ser. 2018.

6. Baltic, T., et al. Packaging as a tool to improve the shelf life of poultry meat. in IOP Conference Series: Earth and Environmental Science. 2019. IOP Publishing.

7. Castañeda-Gulla, K., E. Sattlegger, and A.N. Mutukumira, Persistent contamination of Salmonella, Campylobacter, Escherichia coli, and Staphylococcus aureus at a broiler farm in New Zealand. Canadian Journal of Microbiology, 2020. 66(999): p. 1-15.

8. GAIN, GAIN, 2017. 2017.

9. Asante-Addo, C. and D. Weible, Imported Versus Domestic Chicken Consumption in Ghana: Do Attitudes and Perceptions Matter? Journal of International Food \& Agribusiness Marketing, 2020: p. 1-24.

10. Asante-Addo, C., D. Weible, and J. Pelikan, Consumers' preferences and demand for poultry meat in Ghana. Agribusiness. 36(2): p. 281-298.

11. Weible, D. and J. Pelikan, Imported chicken meat in Ghana: A threat for domestic producers and a blessing for consumers? 2016.

12. Asante-Addo, C. and D. Weible, Is there hope for domestically produced poultry meat? A choice experiment of consumers in Ghana. Agribusiness, 2020. 36(2): p. 281-298.

13. Asante-Addo, C. and D. Weible, "Everybody Likes Chicken"-A Focus Group Study on Consumers in Ghana. 2019.

14. Bannor, R.K., et al., Consumer segmentation and preference for indigenous chicken products. Journal of Agribusiness in Developing and Emerging Economies, 2020.

15. Pesewu, G., et al., Bacterial contaminants of raw broiler meat sold at Korle-Gonno, Accra, Ghana. 2018.

16. Kunadu, A., The microbiological quality of imported frozen chicken drumsticks from retail meat shops in Accra, Ghana. 2018.

17. GSS, Demographic and Health Survey in Ghana Statistical Service. 2014. 
18. Cheesbrough, M., District laboratory practice in tropical countries. 2006: Cambridge university press.

19. Yar, D.D., Bacterial Contaminants and Antibiogram of Ghana Paper Currency Notes in Circulation and Their Associated Health Risks in Asante-Mampong, Ghana. International Journal of Microbiology, 2020. 2020.

20. Ogu, G.I., et al., Mycological Quality of Fresh and Frozen Chicken Meat Retailed within Warri Metropolis, Delta State, Nigeria. Jordan Journal of Biological Sciences, 2017. 10(4).

21. Forbes, B.A., D.F. Sahm, and A.S. Weissfeld, Bailey \& Scott's diagnostic microbiology. 2007: Mosby.

22. Zakki, S.A., et al., Microbial quality evaluation and prevalence of bacteria and fungus in different varieties of chicken meat in Lahore. RADS Journal of Pharmacy and Pharmaceutical Sciences, 2017. 5(1): p. 30-37.

23. Mahami, T., et al., Microbial Food Safety Risk to Humans Associated with Poultry Feed: The Role of Irradiation. International journal of food science, 2019. 2019.

24. Food, U.S. and A. Drug, Centre for Food Safety and Applied Nutrition. Office of Food Additive Safety, Guidance for Industry, Preparation of Food Contact Notifications for Food Contact Substances: Toxicological Recommendations, Final Guidance, 2002.

25. Safety, C.f.F., Microbiological Guidelines for Ready-To-Eat Food in General and Specific Food Items, Centre for Food Safety,, . 2014, Food and Environmental Hygiene Department: 43/F Queensway Government Offices, 66 Queensway, Hong Kong.

26. Bano, Y.J.A.a.S., The Critical Link Between Knowledge Management and Succession Management at Higher Education Institutions. 2020.

27. Hulankova, R., et al., Microbiological quality of organic chicken meat during refrigerated storage in air and modified atmospheres. British poultry science, 2018. 59(5): p. 506-513.

28. Abraham, A.-G., T.-T. Wellington, and A. Victoria, Microbiological quality of chicken sold in Accra and determination of D 10-value of E. coli. Food and Nutrition Sciences, 2012. 2012.

29. Kunadu, A.P.-H., R.Y. Otwey, and L. Mosi, Microbiological quality and Salmonella prevalence, serovar distribution and antimicrobial resistance associated with informal raw chicken processing in Accra, Ghana. Food Control, 2020. 118: p. 107440.

30. Somda, N.S., et al., Safety of ready-to-eat chicken in Burkina Faso: Microbiological quality, antibiotic resistance, and virulence genes in Escherichia coli isolated from chicken samples of Ouagadougou. Food science \& nutrition, 2018. 6(4): p. 1077-1084. 
31. Bohara, M.S., Bacteriological quality of broiler chicken meat sold at local market of Kanchanpur district Nepal. International Journal of Life Sciences and Technology, 2017. 10(9): p. 79.

32. Kozačinski, L., et al., Evaluation of shelf life of pre-packed cut poultry meat. Veterinarski arhiv, 2012. 82(1): p. 47-58.

33. Bhandari, N., D. Nepali, and S. Paudyal, Assessment of bacterial load in broiler chicken meat from the retail meat shops in Chitwan, Nepal. International Journal of Infection and Microbiology, 2013. 2(3): p. 99-104.

34. Javadi, A. and S. Safarmashaei, Microbial profile of marketed broiler meat. Middle-East J. Sci. Res, 2011. 9(5): p. 652-656.

35. Sengupta, R., et al., Commonly occurring bacterial pathogens affecting the quality of Chicken meat. Int J Chem Biochem Sci, 2012. 1: p. 21-3.

36. Joshi, N. and R. Joshi, Bacteriological quality of meat sold in retail market in Uttar Pradesh. Journal of Veterinary Public Health, 2010. 8(2): p. 137-139.

37. Maharjan, S., et al., Microbial quality of poultry meat in an ISO 22000: 2005 certified poultry processing plant of Kathmandu valley. International Journal of Food Contamination, 2019. 6(1): p. 1-9.

38. Dsani, E., et al., Antimicrobial resistance and molecular detection of extended spectrum $\beta$ lactamase producing Escherichia coli isolates from raw meat in Greater Accra region, Ghana. BMC microbiology, 2020. 20(1): p. 1-8.

39. Fahim, A.S., Microbiological Quality of Chicken Carcasses at Modern Poultry Plant. J. Nutrition and Food Processing, 2020. 3(1).

40. Khalafalla, F., et al., Food poisoning microorganisms in chicken broiler meat. Global Veterinaria, 2015. 14(2): p. 211-218.

41. Umaraw, P., et al., Control of campylobacter in poultry industry from farm to poultry processing unit: A review. Critical reviews in food science and nutrition, 2017. 57(4): p. 659-665.

42. Mansour, A.M., Bacteriological Assessment of Chicken Meat, Chicken Meat Products and Its Impact of Human Enteric Infections in Taif Governorate. Journal of Advances in Biology \& Biotechnology, 2019: p. 1-10.

43. Stanley, C.N. and V.O. Arueyingho, Microbiological Evaluation and Antibiotic Susceptibility Patterns of Organisms Isolated from Frozen Chicken Products Sold in Port Harcourt, Nigeria. Journal of Pharmaceutical Research International, 2018: p. 1-7. 
44. Carrasco, E., A. Morales-Rueda, and R.M. García-Gimeno, Cross-contamination and recontamination by Salmonella in foods: a review. Food Research International, 2012. 45(2): p. 545-556.

45. Petracci, M., M. Bianchi, and C. Cavani, Pre-slaughter handling and slaughtering factors influencing poultry product quality. World's Poultry Science Journal, 2010. 66(1): p. 1726.

46. Althaus, D., C. Zweifel, and R. Stephan, Analysis of a poultry slaughter process: Influence of process stages on the microbiological contamination of broiler carcasses. Italian journal of food safety, 2017. 6(4).

47. Milios, K.T., E.H. Drosinos, and P.E. Zoiopoulos, Food Safety Management System validation and verification in meat industry: Carcass sampling methods for microbiological hygiene criteria-A review. Food Control, 2014. 43: p. 74-81.

48. Boysen, L., M. Nauta, and H. Rosenquist, Campylobacter spp. and Escherichia coli contamination of broiler carcasses across the slaughter line in Danish slaughterhouses. Microbial Risk Analysis, 2016. 2: p. 63-67.

49. Naugle, A.L., et al., US Food Safety and Inspection Service testing for Salmonella in selected raw meat and poultry products in the United States, 1998 through 2003: analysis of set results. Journal of food protection, 2006. 69(11): p. 2607-2614.

50. Khalafalla, F., H. Ali, and A. El-Fouley, Microbiological evaluation of chicken meat products. Journal of Veterinary Medical Research, 2019. 26(2): p. 151-163.

51. Zakki, S.A., et al., Microbial quality evaluation and prevalence of bacteria and fungus in different varieties of chicken meat in Lahore. 2017. 5(1): p. 30-37.

52. Haleem, A.M., S.A. Al-bakri, and S.A.J.J.o.M.R. Al-Hiyaly, Determination of microbial content in poultry meat in local Iraqi markets. 2013. 3(6): p. 205-207.

53. Jerry, O., et al., Microbial contamination of ready-to-eat fried chicken meat sold in two selected motor park points in Abakaliki, Ebonyi State, Nigeria. 2015. 3(4): p. 271-275.

54. Enyisi, S., et al., Total aflatoxin level and fungi contamination of maize and maize products. 2015. 6(8): p. 229-233.

55. Zain, M.E.J.J.o.S.c.s., Impact of mycotoxins on humans and animals. 2011. 15(2): p. 129144.

56. Ismaiel, A.A. and J.J.A. Papenbrock, Mycotoxins: producing fungi and mechanisms of phytotoxicity. 2015. 5(3): p. 492-537. 
57. Atanda, O., et al., Fungal and mycotoxin contamination of Nigerian foods and feeds. 2013: p. 3-38. 